\title{
35. The Control of Growth and Development in Bombyx mori. XXI
}

Function of the Brain by Strains in the Activity of the Corpora Allata of the Fifth Instar Larvae

\author{
By Seijiro Morohoshi and Jun ShimadA \\ Faculty of Agriculture, Tokyo University of Agriculture and Technology \\ Fuchu-shi, Tokyo 183
}

(Comm. by Hitoshi Kinara, M. J. A., Feb. 12, 1974)

It was demonstrated in this series (XVII) that the brain innervates the secretion of the corpora allata (CA) through nerve commissures from the brain. As the sex-linked allelomorphic maturing genes $\left(L m^{e}<+{ }^{L m}<L m\right)$ had been thought to control the function of the brain, the function of the brain by strains (genes) in the CA during the final 5th larval instar was investigated. From experimental results, it was demonstrated that the recessive early maturing gene $\mathrm{Lm}^{e}$, on the $\mathrm{Z}$ chromosome strongly, the intermediate maturing gene $+^{L m}$, intermediately, and the dominant maturing gene $L m$, weakly innervates the activity of the CA of the 5th instar larvae.

Materials and methods. The silkworms used in this experiment were larvae of four tetramolting crossings between J. $106\left(+^{v} /+^{v}\right.$, $\left.\mathrm{Z}^{+{ }^{L m}} / \mathrm{W}\right)$ and $\mathrm{T}_{2}\left(+^{V} /+^{V}, \mathrm{Z}^{L m^{e}} / \mathrm{Z}^{L m^{e}}\right)$, between J. 106 and $\mathrm{Di}\left(+^{V} /+^{V}\right.$, $\left.\mathrm{Z}^{+L m} / \mathrm{Z}^{+L m}\right)$, between J. 106 and $\mathrm{Kp}\left(+^{V} /+^{V}, \mathrm{Z}^{L m} / \mathrm{Z}^{L m}\right)$, between E. 606 $\left(V^{1} / V^{1}, \mathrm{Z}^{L m} / \mathrm{W}\right)$ and $\mathrm{c}\left(V^{3} / V^{3}, \mathrm{Z}^{L m^{e}} / \mathrm{Z}^{L m^{e}}\right)$ and larvae of reciprocal crossings between $\mathrm{T}_{2}$ and $\mathrm{Kp}$. Their eggs were incubated at $25^{\circ} \mathrm{C}$ in the light. Operating methods for the extirpation of the $\mathrm{CA}$ or the transplantation of the brain-corpora allata (Br-CA) complex or the CA were the same as the one previously reported (Report XVII). This experiment was ascertained by repeating two times.

Results. 1. Function of the $\mathrm{Br}-\mathrm{CA}$ and the $\mathrm{CA}$ during 4th and 5th larval instar. The activity of the Br-CA and the CA during the 4th larval instar was stronger, especially in the late half instar as compared with that of the Br-CA and the CA during the 5th larval instar as shown in Figs. 1 and 3. The secretion of the CA during the 4th instar continued until the 4th molting, but during the 5th instar it decreased with age and ceased at the middle stage of the same instar. The Br-CA always showed stronger activity than the CA. According to thin-layer chromatography (Report XIX), ecdy- 
sone analogue gradually begins to accumulate in the larval haemolymph on the 3rd day of the 5th instar and amounts to the top of the accumulation in the spinning stage. However, the rise and fall of ecdysone analogue in the 5th instar larval haemolymph was quickened by about 1 day under the condition of lacking of the CA. Accordingly, the CA hormone seems to control the initiation and secretion of the prothoracic gland hormone.

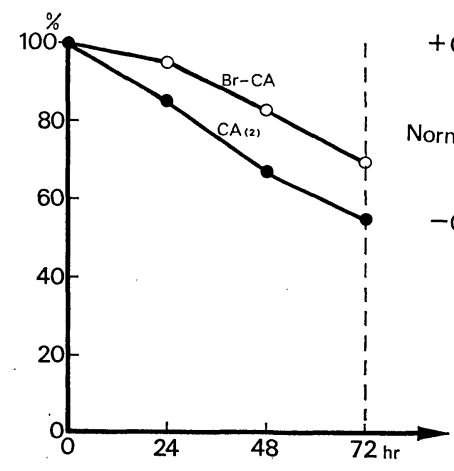

Fig. 1

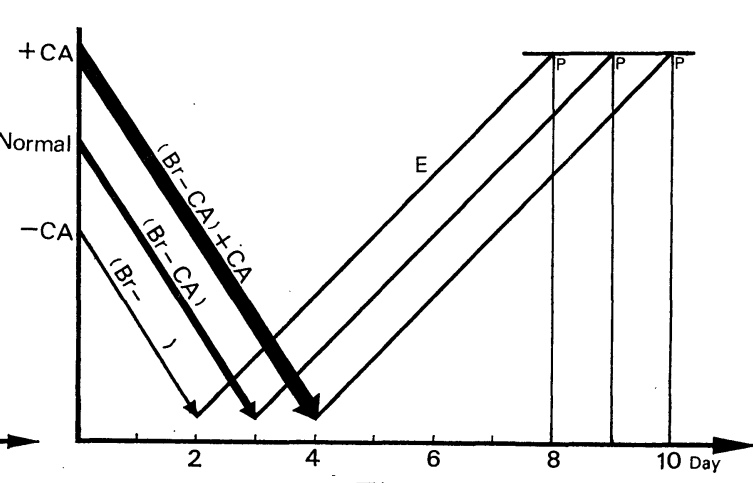

Fig. 2

Fig. 1. Function of the Br-CA and the CA during 4th larval instar (J.106 $\times$ Di, reared at $25^{\circ} \mathrm{C}$ ). Abscissa: age (hr) in 4 th instar of donors. Ordinate: \% of larval ecdysis type, CA(2): two corpora allata. The 72-hr-old stage is during 4th molting.

Fig. 2. Diagram illustrating relationship between activity of the CA and length of 5th larval instar. Abscissa: age (day) in 5th instar. Ordinate: activity of the CA, E: function of ecdysone, P: pupating stage.

Table I. Effect of the Br-CA complex and the CA by genes on larval or pupal ecdysis of the allatectomized 4th instar larvae

\begin{tabular}{|c|c|c|c|c|c|c|c|c|c|c|}
\hline \multirow{3}{*}{$\begin{array}{l}\text { Recipi- } \\
\text { ent }\end{array}$} & \multirow{3}{*}{ 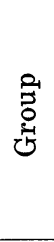 } & \multicolumn{2}{|c|}{ Donor } & \multicolumn{6}{|c|}{ Transplantation } & \multirow{3}{*}{$\begin{array}{l}\text { Length }(\mathrm{hr}) \\
\text { of } 5 \mathrm{th} \\
\text { instar in } \\
\text { female } \\
\text { donors }\end{array}$} \\
\hline & & \multirow[b]{2}{*}{ Race } & \multirow{2}{*}{ 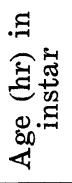 } & \multicolumn{3}{|c|}{$\mathrm{Br}-\mathrm{CA}$} & \multicolumn{3}{|c|}{$\mathrm{CA}$} & \\
\hline & & & & 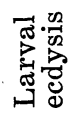 & 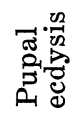 & 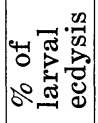 & 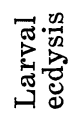 & 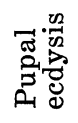 & 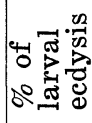 & \\
\hline \multirow{3}{*}{ 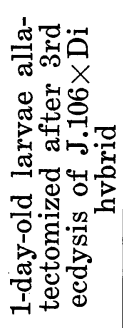 } & I & $\begin{array}{l}\text { 우 }\left(\boldsymbol{J} m^{e}\right) \text { of } \\
\mathrm{J} .106 \times \mathrm{T}_{2}\end{array}$ & $\begin{array}{r}0 \\
24 \\
48\end{array}$ & $\begin{array}{r}30 \\
19 \\
1\end{array}$ & $\begin{array}{r}5 \\
16 \\
30\end{array}$ & $\begin{array}{r}86 \\
54 \\
3\end{array}$ & $\begin{array}{r}22 \\
9 \\
1\end{array}$ & $\begin{array}{r}8 \\
22 \\
30\end{array}$ & $\begin{array}{r}73 \\
30 \\
3\end{array}$ & 181 \\
\hline & II & $\begin{array}{l}\text { 우 }\left(+{ }^{L m}\right) \text { of } \\
\text { J.106× Di }\end{array}$ & $\begin{array}{r}0 \\
24 \\
48\end{array}$ & $\begin{array}{r}33 \\
26 \\
3\end{array}$ & $\begin{array}{r}3 \\
10 \\
31\end{array}$ & $\begin{array}{l}92 \\
72 \\
10\end{array}$ & $\begin{array}{r}30 \\
22 \\
2\end{array}$ & $\begin{array}{r}6 \\
16 \\
35\end{array}$ & $\begin{array}{r}83 \\
58 \\
6\end{array}$ & 187 \\
\hline & III & $\begin{array}{l}\text { 우 }(\mathrm{Lm}) \text { of } \\
\mathrm{J.106} \times \mathrm{Kp}\end{array}$ & $\begin{array}{r}0 \\
24 \\
48\end{array}$ & $\begin{array}{r}37 \\
30 \\
3\end{array}$ & $\begin{array}{r}0 \\
8 \\
26\end{array}$ & $\begin{array}{r}100 \\
79 \\
10\end{array}$ & $\begin{array}{r}37 \\
25 \\
2\end{array}$ & $\begin{array}{r}3 \\
13 \\
28\end{array}$ & $\begin{array}{r}93 \\
68 \\
7\end{array}$ & 193 \\
\hline
\end{tabular}


From above mentioned results, the rise and fall of two kinds of hormone during the 5th instar is shown in Fig. 2. And the larval duration of the 5th instar is mainly determined by the activity of the $\mathrm{Br}-\mathrm{CA}$ system. The 5th larval instar length is lengthened by transplantation of the CA and is shortened by allatectomy.

2. Function of the brain by strains in the activity of the CA during 5th instar. From the experimental results of Table I and Fig. 3, we know two distinct facts; one is that the function of the $\mathrm{Br}-\mathrm{CA}$ or the $\mathrm{CA}$ in the female larvae (gene constitution, $\mathrm{Z}^{L m^{e}} / \mathrm{W}$ ) of group I is the weakest among those of three groups, and the other is that the functional difference between the $\mathrm{Br}-\mathrm{CA}$ and the $\mathrm{CA}$ is the greatest in the female larvae of group I among those three groups.
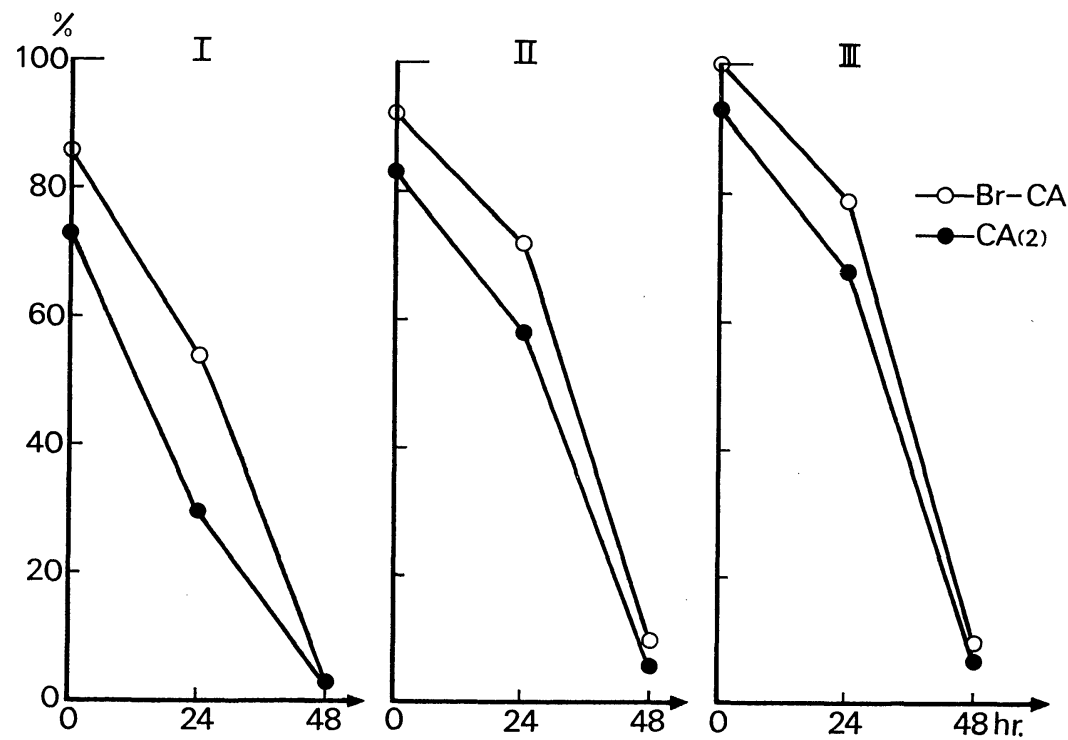

Fig. 3. Function of the Br-CA and the $\mathrm{CA}$ during 5th larval instar by three kinds of the sex-linked maturing gene. Abscissa: age (hr) in 5th instar of donors, Ordinate: \% of larval ecdysis, I: 우 $\left(\mathrm{Lm}^{\mathrm{e}}\right)$ of $\mathrm{J} .106 \times \mathrm{T}_{2}$, II: 우 $\left(+{ }^{L m}\right)$ of J.106 $\times \mathrm{Di}$, III: 우 $(L m)$ of $\mathrm{J} .106 \times \mathrm{Kp}$.

3. Effect of the Br-CA and the CA by male and female on larval or pupal ecdysis of the allatectomized 4th instar larvae. Larval length of the 5th instar is commonly longer in females than in males. However, as shown in Table II, the crossing of $\mathrm{Kp}\left(\mathrm{Z}^{L m} / \mathrm{W}\right)$ o $\times \mathrm{T}_{2}\left(\mathrm{Z}^{L m^{e}} / \mathrm{Z}^{L m^{e}}\right)$ o is somewhat shorter in females than in males. The reciprocal crossing, $\mathrm{T}_{2}\left(\mathrm{Z}^{L m e} / \mathrm{W}\right) \circ \times \mathrm{Kp}\left(\mathrm{Z}^{L m} / \mathrm{Z}^{L m}\right)$ of is somewhat longer in females than in males. The activity of the Br-CA and the $\mathrm{CA}$ in these larvae was minutely in parallel with the larval length of the 5th instar; the weaker the activity of the Br-CA, the 
Table II. Effect of the Br-CA and the CA by male and female on larval or pupal ecdysis of the allatectomized 4th instar larvae

\begin{tabular}{|c|c|c|c|c|c|c|}
\hline \multirow{2}{*}{ Recipient } & \multicolumn{2}{|r|}{ Donor } & \multirow{2}{*}{$\begin{array}{l}\text { Larval } \\
\text { ecdysis }\end{array}$} & \multirow{2}{*}{$\begin{array}{l}\text { Pupal } \\
\text { ecdysis }\end{array}$} & \multirow{2}{*}{$\begin{array}{c}\% \text { of } \\
\text { larval } \\
\text { ecdysis }\end{array}$} & \multirow{2}{*}{$\begin{array}{l}\text { Length (hr) } \\
\text { of } 5 \mathrm{th} \\
\text { instar in } \\
\text { donors }\end{array}$} \\
\hline & Race & $\begin{array}{l}\text { Organ of 12-hr-old- } \\
5 \text { th instar larvae }\end{array}$ & & & & \\
\hline \multirow{4}{*}{$\begin{array}{l}\text { 1-day-old } \\
\text { larvae alla- } \\
\text { tectomized } \\
\text { after } 3 \mathrm{rd} \\
\text { larval } \\
\text { ecdysis of } \\
\mathrm{J.106} \times \mathrm{Di}\end{array}$} & \multirow{2}{*}{$\underset{\times \mathrm{T}_{2}}{\mathrm{Kp}}($ (우) } & 우 $\left\{\begin{array}{l}\mathrm{Br}\left(\mathrm{Lm}^{e}\right)-\mathrm{CA} \\
\mathrm{CA}\end{array}\right.$ & $\begin{array}{l}16 \\
11\end{array}$ & $\begin{array}{l}4 \\
9\end{array}$ & $\begin{array}{l}80 \\
55\end{array}$ & 182 \\
\hline & & 今 $\left\{\begin{array}{l}\mathrm{Br}\left(L m / L m^{e}\right)-\mathrm{CA} \\
\mathbf{C A}\end{array}\right.$ & $\begin{array}{l}18 \\
15\end{array}$ & $\begin{array}{l}2 \\
5\end{array}$ & $\begin{array}{l}90 \\
75\end{array}$ & 192 \\
\hline & \multirow{2}{*}{$\begin{array}{l}\mathrm{T}_{2}(\text { 우) } \\
\times \mathrm{Kp}(\hat{\sigma})\end{array}$} & 우 $\left\{\begin{array}{l}\mathrm{Br}(L m)-\mathrm{CA} \\
\mathrm{CA}\end{array}\right.$ & $\begin{array}{l}18 \\
15\end{array}$ & $\begin{array}{l}1 \\
5\end{array}$ & $\begin{array}{l}94 \\
75\end{array}$ & 194 \\
\hline & & 令 $\left\{\begin{array}{l}\mathrm{Br}\left(L m / L m^{e}\right)-\mathrm{CA} \\
\mathbf{C A}\end{array}\right.$ & $\begin{array}{l}17 \\
14\end{array}$ & $\begin{array}{l}2 \\
5\end{array}$ & $\begin{array}{l}89 \\
74\end{array}$ & 191 \\
\hline
\end{tabular}

shorter becomes the larval length of the 5th instar.

Discussion. Different races of silkworms are characterized by undergoing 3, 4 and 5 molts during larval life. The duration of each larval instar is longer in trimolting than in pentamolting. The activity of the CA in any strain becomes weaker in the final instar. It was already discussed by Morohoshi and Shimada (Report XIV) that the activity of the $\mathrm{CA}$ is the strongest in trimolting, intermediate in tetramolting and the weakest in pentamolting. Why is trimolting which is the strongest in the inherent activity of the CA the shortest in whole larval life, and why is pentamolting which is the weakest in the inherent activity of the CA the longest in whole larval life? This is due to the fact that it is regulated by the larval molting of each instar as shown in Fig. 4. Now, when the middle stage of larval life is thought as the boundary of the earlier and the later larval development, the relative duration of each larval instar in three molting strains is sketched as in shown Fig. 4.

Fig. 4 shows that the activity of the CA of the 4 th instar larvae in three strains is the strongest in pentamolting, intermediate in tetramolting and the weakest in trimolting. This may be due to larval

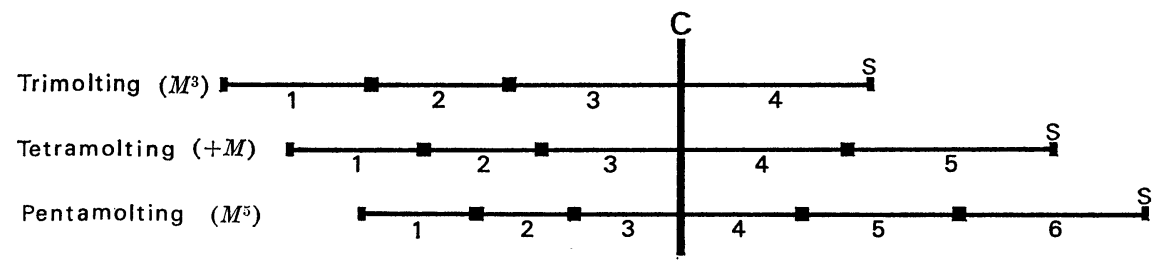

Fig. 4. Diagram illustrating relative duration of each larval instar in three molting strains. $M^{3},{ }^{M}, M^{5}$ : major genes controlling tri-, tetra- and pentamolting, 1, 2, 3, 4, 5, 6: each larval instar, C: critical stage in 3rd molting, $\mathrm{S}$ : spinning stage. 
age (spent days). For the CA of the 4 th instar larvae is the youngest in pentamolting and the oldest in trimolting.

The larvae having the $L m^{e}$ gene showed the weaker activity in the Br-CA and the $\mathrm{CA}$ during the 5th instar, and showed greater difference in function between the $\mathrm{Br}-\mathrm{CA}$ and the $\mathrm{CA}$. This seems to be due to a strong stimulation of the brain to the CA. Since the brain controlled by the $\mathrm{Lm}^{e}$ gene strongly innervates the CA through nerve commissures, much CA hormone is secreted during the earlier larval instars but less CA hormone during the later larval instars. For the CA is too small to secret unchangingly during whole larval life. Accordingly, when "tetramolting and bivoltine larvae" having the $L m^{e}$ gene are incubated at low temperature, some of them are apt to be trimolters in the earlier stage and many of them are apt to be "non-diapause insects" in the later stage as shown in Table III.

Table III. Sex-linked phenomenon of quantitative characters in the reciprocal crossing between univoltine E.606 and multivoltine c

\begin{tabular}{|c|c|c|c|c|c|}
\hline $\begin{array}{l}\text { Reciprocal crossing } \\
\text { (gene constitution) }\end{array}$ & $\begin{array}{c}\text { Larval } \\
\text { and pupal } \\
\text { period (hr) }\end{array}$ & $\begin{array}{l}\text { Cocoon } \\
\text { weight } \\
(\mathrm{g})\end{array}$ & $\begin{array}{l}\text { Cocoon } \\
\text { shell (cg) }\end{array}$ & $\begin{array}{c}\% \text { of } \\
\text { trimolters }\end{array}$ & $\begin{array}{c}\% \text { of "non- } \\
\text { diapause } \\
\text { moths" }\end{array}$ \\
\hline $\begin{array}{l}\text { E.606 (ㅇ }) \times c(\text { c }(\hat{)}) \\
\left(\mathbf{Z}^{L m} / \mathrm{W} \times \mathbf{Z}^{L m e} / \mathbf{Z}^{L m e}\right)\end{array}$ & $\begin{array}{l}\text { 우, } 755.4 \\
\text { 令, } 785.4\end{array}$ & $\begin{array}{l}1.33 \\
1.51\end{array}$ & $\begin{array}{l}18 \\
22\end{array}$ & $\begin{array}{r}33.0 \\
0.0\end{array}$ & 68.2 \\
\hline $\begin{array}{l}\text { c }(\text { 우 }) \times \mathrm{E} .606(\text { 令) } \\
\left(\mathbf{Z}^{L m e} / \mathrm{W} \times \mathbf{Z}^{L m} / \mathbf{Z}^{L m}\right)\end{array}$ & $\begin{array}{l}\text { 우, } 832.2 \\
\text { 占, } 785.9\end{array}$ & $\begin{array}{l}1.79 \\
1.50\end{array}$ & $\begin{array}{l}26 \\
22\end{array}$ & $\begin{array}{l}0.0 \\
0.0\end{array}$ & $\underline{0.0}$ \\
\hline
\end{tabular}

Table III shows sex-linked phenomena of quantitative characters in the reciprocal crossing between univoltine E. 606 and multivoltine c. Therefore, the rise and fall of the $\mathrm{CA}$ hormone by the function of genes controlling the brain during larval life is as follows:

Stimulation of the brain to the CA 1st-3rd instars 4th-5th instars

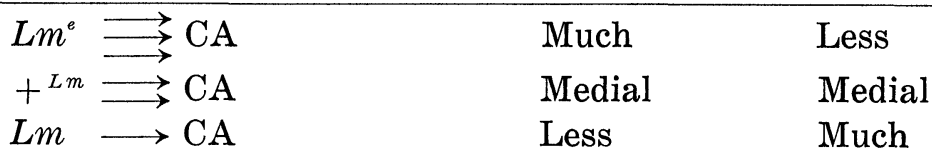

The relative duration of each larval instar based on the sexlinked maturing genes is sketched as Fig. 5.

From Fig. 5 the activity of the CA of the 4th instar larvae in three strains is the strongest in the larvae having the $L m$ gene, intermediate in the larvae having the $+{ }^{L m}$ gene and the weakest in the larvae having the $L m^{e}$ gene. The ability of the Br-CA system seems to be different between in the earlier and in the later stages of larval development. Namely, although the Br-CA has a strong ability to regulate the development in the earlier stage, but the development changes according to the activity of the Br-CA system in the later 


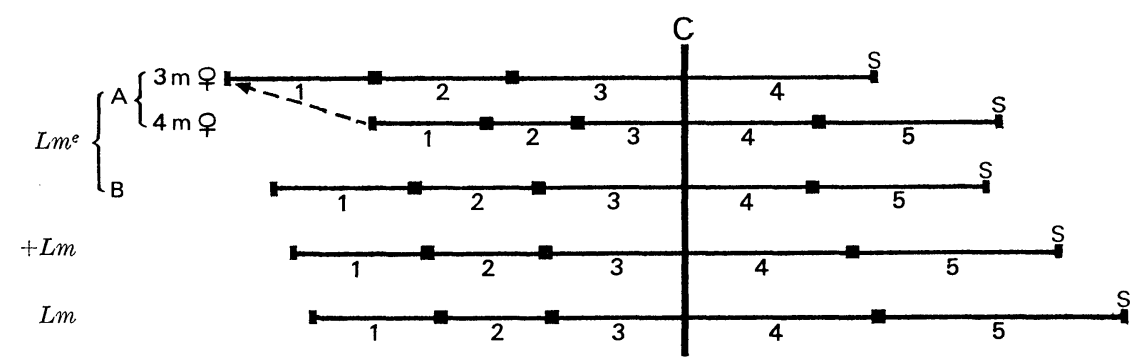

Fig. 5. Diagram illustrating relative duration of each larval instar by three kinds of the sex-linked maturing gene. $\mathrm{Lm}^{e},{ }^{\mathrm{Lm}}, \mathrm{Lm}$ : early, intermediate and late maturing genes, 1, 2, 3, 4, 5: each larval instar, C: critical stage in 3rd molting, $\mathrm{S}$ : spinning stage, $\mathrm{A}$ : 우 of bi- or univoltine (우) $\times$ multivoltine (卉), B: original race.

stage. In the scope of a certain quantity of the CA hormone, the greater the quantity of the CA hormone, the shorter becomes each instar in the earlier larval instars but the longer becomes each instar in the later larval instars. However, when the activity of the Br-CA system of tetramolting silkworms such as the hybrid (Fig. 5) having the $L m^{e}$ gene is strengthened until a critical limit during the earlier larval stage, some of them prolong the length of instar and become trimolters. On the other hand, when it is weakened until a critical limit, some of them shorten the length of instar and become pentamolters. We can know that a significantly physiological boundary exists between the earlier and later larval stages.

The rise and fall of the $\mathrm{CA}$ during larval life depends on the function of the brain controlling the CA. The secretion of the CA hormone may be produced much in the male having two sex-linked genes than in the female havnig one sex-linked gene at the earlier instars but it becomes less in the male than in the female at the later instars. However, when the gene controlling the function of the brain is different between male and female as shown in Table II, the rise and fall of the CA during larval life becomes different between male and female as shown in the crossing of Table IV.

Table IV. Rise and fall of the CA hormone during larval life based on the gene constitution of male and female

\begin{tabular}{c|l|c|c}
\hline \multicolumn{1}{c|}{ Race } & Male and female (gene constitution) & $\begin{array}{c}\text { 1st-3rd } \\
\text { instars }\end{array}$ & $\begin{array}{c}\text { 4th-5th } \\
\text { instars }\end{array}$ \\
\cline { 2 - 3 } Original races & $\begin{array}{l}\text { Male }\left(L m / L m,+L m /+L m, L m^{e} / L m^{e}\right) \\
\text { Female }\left(L m,+L m, L m^{e}\right)\end{array}$ & $\begin{array}{l}\text { Much } \\
\text { Less }\end{array}$ & $\begin{array}{l}\text { Less } \\
\text { Much }\end{array}$ \\
\cline { 2 - 3 } J.106 (ㅇ $) \times \mathrm{T}_{2}(\hat{\delta})$ & $\begin{array}{l}\text { Male }\left(+L m / L m^{e}\right) \\
\text { Female }\left(L m^{e}\right)\end{array}$ & $\begin{array}{l}\text { Less } \\
\text { Much }\end{array}$ & $\begin{array}{l}\text { Much } \\
\text { Less }\end{array}$ \\
\hline
\end{tabular}

By this investigation it has become clear that the function of the sex-linked maturing gene is differentiated in the brain cell. 